Eduvest - Journal of Universal Studies

Volume 1 Number 11, November 2021

p- ISSN 2775-3735 e-ISSN 2775-3727

\title{
PULSE OF AMENDMENT OF ARTICLE 7 OF THE 1945 CONSTITUTION DURING THE COVID-19 PANDEMIC IN INDONESIA
}

\section{Dony Yusra Pebrianto, Sabri Yanto, Yanita Kusuma}

Jambi University, Indonesia

E-mail:yudianton@gmail.com, sabri.siaranpers@gmail.com, yanitaks@gmail.com

\begin{tabular}{|c|c|}
\hline ARTICLE INFO & ABSTRACT \\
\hline $\begin{array}{l}\text { Received: } \\
\text { October, } 26^{\text {th }} \\
2021 \\
\text { Revised: } \\
\text { November, } 17^{\text {th }} \\
2021 \\
\text { Approved: } \\
\text { November, 19th } \\
2021\end{array}$ & $\begin{array}{l}\text { The issue of the amendment of article } 7 \text { of the } 1945 \\
\text { Constitution in Indonesia has caused an uproar among the } \\
\text { public during the COVID } 19 \text { pandemic. Although } \\
\text { constitutionally amendments can be made as article } 37 \text { of } \\
\text { the } 1945 \text { Constitution, it needs to be seen from three } \\
\text { sections, namely: 1. Changing the constitution with } \\
\text { careful consideration, not carelessness and self- } \\
\text { awareness; } 2 \text {. Give people the opportunity to express their } \\
\text { views before making changes; 3. Protect the rights of } \\
\text { individuals or minorities. The results of several survey } \\
\text { institutions in Indonesia amendments to the three-term } \\
\text { presidential term some Indonesians refused. The purpose } \\
\text { of this study is to provide a scientific foundation on the } \\
\text { pulse rate of the } 1945 \text { Constitution during the current } \\
\text { COVID-19 pandemic in Indonesia. The purpose of this } \\
\text { study is to provide a scientific foundation on the pulse rate } \\
\text { of the } 1945 \text { Constitution during the current COVID-19 } \\
\text { pandemic in Indonesia. The study uses normative legal } \\
\text { methods, using three methods, namely: legal methods, } \\
\text { historical methods, and conceptual methods. The } \\
\text { recommendation of this study is to provide advice and } \\
\text { input to JokPro groups and government support parties in } \\
\text { the discourse of the idea of a three-term president related } \\
\text { to article } 7 \text { of the } 1945 \text { Constitution. }\end{array}$ \\
\hline
\end{tabular}

Dony Yusra Pebrianto, Sabri Yanto, Yanita Kusuma.(2021).Pulse of Amendment of Article 7 of the 1945 Constitution during the Covid19 Pandemic in Indonesia. Journal Eduvest. 1(11): 1357-1365

How to cite:

E-ISSN:

Published by: https://greenpublisher.id/ 


\begin{tabular}{ll}
\hline KEYWORDS & Amendments, 1945 Constitution, Constitution, Covid-19 \\
\hline CC) (?) (O) & $\begin{array}{l}\text { This work is licensed under a Creative Commons } \\
\text { Attribution-ShareAlike 4.0 International }\end{array}$ \\
\hline
\end{tabular}

\section{INTRODUCTION}

The issue of the election of three presidential terms resurfaced and emerged in the current government. The discourse led to discourse among academics, political parties, researchers, and the public. Although the discourse was vociferously echoed in the era of President Joko Widodo's government, but actually in the era of President Susilo Bambang Yudhoyono's leadership, this discourse has begun to be proposed (Center for Constitutional Law Studies Faculty of Law UII, 2021).

With the discourse to bring back, this is highly expected by JokPro, namely the Jokowi and Prabowo 2024 communities that continue to encourage President Joko Widodo and Prabowo Subianto to participate in the 2024 presidential election (Fransiskus Adhiyuda Prasetia, 2021). According to M. Qodari in Prasetia (2021) as an advisor, JokPro 2024 said optimistically that the amendment of the 1945 Constitution regarding the presidential term to three periods is very possible as long as the conditions specified in the 1945 Indonesian Constitution can be fulfilled. While according to Mardani Ali in Rolando Fransiscus Sihombing (2021) he said that currently, everyone is struggling to cope with the COVID-19 pandemic, therefore the 1945 Constitution is hoped not to be done at this time.

Besides Mardani Ali in Amalia Salabi (2021) the conflict over the idea of a threeterm president is also opposed by some researchers such as:

Feri Ansari of the Constitution Research Center (Pusako) of Andalas University stated that "The amendment of Article 7 of the Basic Law deviates from the desire of all members of the Constitution at the time to avoid authoritarianism from the unlimited authority of the President. Therefore, Article 7 is very clear".

1. Hadar Nafis Gumay of the Election Integrity and Democracy Network (Netgrit) stated: "The idea of a three-term presidential term is deeply insulting to the diverse Indonesian nation. With the emergence of potential figures in various regions in Indonesia, I think this can open the opportunity to become President of Indonesia, he has the right to appeal and remind the public to be careful with the remarks of extending the presidential term. As is the case in some countries, the COVID-19 pandemic is used as an excuse to expand power.

2. Fadli Ramadhanil of the Project manager of the Electoral and Democratic Society (Perludem) said, "We oppose the idea of a three-term presidential term because a healthy democracy should not focus on actors or figures who are judged to be working well but in a fair and open system. Let different groups of people participate and have equal opportunities".

3. The issue of the three-term amendment during the COVID-19 pandemic has caused uproar in society, driven by the influence of current political power. While the survey results according to Saiful Mujani in Syahrizal Sidik (2021) from Research and Consulting (SMRC) Indonesian society rejects the discourse of a three-term term, Similarly, the results of a survey conducted by the Center for Strategic Actions of Indonesia (CISA) survey showed from 58.25 percent of respondents who said they disagreed with the increase in the presidential term to 3 (three) times the period (Survei CISA: Mayoritas Tolak Presiden 3 Periode, 2021). Meanwhile, the results of the Survey of Carta Politika showed that $61.3 \%$ 
of the public disagreed with the president's three-term discourse (Wilda Hayatun

Rufus, 2021).

Thus, according to the author of the three-term presidential discourse issue, some Indonesians do not agree with the amendment and have made a polemic during the current COVID-19 pandemic. But constitutionally as Article 7 of the 1945 Constitution states: "The president and vice president serve for a five-year term, and after that can only be re-elected for one term" (Nurjamila Siregar, 2019). This means the positions of president and vice president are maximum twice the term. As well as in (Dicky Eko Prasetio, 2021).

Based on these problems, the author limited the problems and legal arguments studied related to article 7 of the 1945 Constitution. Therefore, scientific steps are needed to review the pulse of article 7 amendments during the COVID 19 pandemic, the discourse that develops in the community will not cause controversy. Thus to answer questions related to public law, this research becomes very important to be discussed on the issue of the three-term presidential amendment discourse during the COVID 19 pandemic.

\section{RESEARCH METHOD}

This research is normative legal research, using three methods, namely: legal methods, historical methods, and conceptual methods. In addition to using literature research, this study also uses primary and secondary techniques to collect legal materials, namely: document tracking, literature books, legal journals, and laws and regulations related to research objects (Prasetyoningsih, 2020). In addition, the data obtained are presented and qualitatively, then analyzed as a basis to conclude (M. Yasin Al-Arif, 2017).

In this study, several journals have conducted related research similar to the author's journal, namely: 1. Nanik Prasetyoningsih discussed the 5th Amendment: Towards a New Constitution in Indonesia, 2. Muwaffiq Jufri discussed the Urgency of the Fifth Amendment in the Constitution of the Republic of Indonesia of 1945 Regarding The Rights and Freedom of Religion, 3. Ro'is Alfauzi and Orien Effendi discussed the Establishment of Power Based on Constitutionalism in Democracies, 4. Mohammad Ibrahim discussed the Restriction of Constitutional Amendment Powers: Theory, Practice in Several Countries and Their Relevance in Indonesia, 5. Taufiqurrohman Syahuri discusses the Method of Amendment of the 1945 Constitution and its Comparison with the Constitution in Several Countries, 6. Dicky Eko Prasetio discusses the Idea of a 3-Term Presidential Office

\section{RESULT AND DISCUSSION}

\section{A Brief History of amendments to the 1945 Constitution}

The 1945 Constitution is the constitution of the Republic of Indonesia and was passed as the country's constitution by the Preparatory Committee for Indonesian Independence (PPKI) on August 18, 1945 or the day after Indonesia proclaimed its independence. Avec la dissolution du RIS, à partir du 17 août 1950, la Loi fondamentale provisoire (UUDS) a été promulguée. En outre, conformément au décret du Président Sukarno du 5 juillet 1959, le 22 juillet 1959, la Chambre des représentants de la République d'Indonésie (RPD) a réannoncé et adopté la Constitution de 1945 par acclamation (Raditya, 2020).

Throughout its history, the 1945 Constitution has undergone four revisions or 
changes, between 1999 and 2002, the changes were made at the annual meeting of the General Assembly and the People's Consultative Assembly (MPR), namely: The First Amendment to the 1945 Constitution was passed at the Plenary Session of the MPR on October 14, 1999, on; The Second Amendment of the 1945 Constitution was passed on August 7, 2000, held at the MPR Annual Session on January 18 to January 18; The Third Amendment of the 1945 Constitution was implemented at the MPR Annual Meeting on November 19, 2001; The Fourth Amendment of the 1945 Constitution at the People's Deliberations on August 11, 2002.

According to Dokuritsu Zyunbi Tyoosakai in Syahuri (2010) The 1945 Constitution was first established and passed by the Preparatory Committee for Indonesian Independence (PPKI) originally formed by the Japanese Balatentara Government under the name "Dokuritsu Zyunbi Inkai", but he stated that the passage of the Basic Law was acting on behalf of the Indonesian nation itself. Thus according to the author of Indonesia has had a constituent since pre-independence. While Taufik Syah (2009) the first constitution approved by BPUPKI was then replaced with a version of PPKI until the Presidential Decree 1959, which was revised in four stages during 1999-2002.

Thus according to the author of the 1945 Constitution as the highest constitutional norm. While according to Jimly Asshiddiqie (2006) the existence of the 1945 Constitution is a constitution that has strategic interests and urgency for a country, both a newly independent country and an independent country. Because the constitution is the basis for regulating the life of the country.

\section{Constitution Amendment}

Deep The Great Dictionary of Indonesian (KBBI) the word amendment or amendment is a form of the word not standard of the word amendment so that in the correct writing is an amendment. While the meaning of the word amendment is the proposed legislative reform proposed by the House of Representatives (KBBI Daring). Thus according to the author of the amendment is a method of constitutional change that is no stranger to constitutional research. In general, as said by Sri Sumantri in Muwaffiq Jupri (2021) the constitution is amended in response to certain changes that require such changes, including in the constitution not out of date.

In the course of state regulations in Indonesia, constitutionally this is done by changing the rules and provisions of the applicable constitution. Although there is an opportunity to amend the 1945 Constitution, as stipulated in Article 37 paragraph (3) of the 1945 Constitution, "To change the provisions of the constitution, the MPR has at least $2 / 3$ of the number of MPR members" realized by making changes to the applicable constitutional rules. Although there is an opportunity in amending the 1945 Constitution, as the formulation of Article 37 paragraph (3) of the 1945 Constitution which reads "To amend the articles of the Basic Law, the Session of the People's Consultative Assembly was attended by at least $2 / 3$ of the number of members of the People's Consultative Assembly". But in the conditions of the covid-19 pandemic, the three-term presidential proposal should be reviewed in advance so that the target of constitutional amendments can be implemented.

According to Prasetyoningsih (2020), the actual amendments should be seen from the three sections, meaning: 1. Change the constitution with careful consideration, not carelessness and conscience (hope); 2. Give people the opportunity to express their opinions before the change; 3 . Guarantee the rights of people or minorities. According to Ibrahim (2020) restriction of the constitutional amendment, power is a logical result of the unconstitutional doctrine of constitutional amendments. The power to restrict constitutional amendments means that the power to change the constitution is unlimited. 
While according to Jon Elster in Alfianus Danny Jema, Harly Stanly Muaja (2020) constitutional changes usually occur due to motivating factors such as economic and social crises, revolutions, the fall of certain regimes, fears of the fall of certain regimes, the defeat of wars, reconstruction after the war, the formation of a new state, and independence from colonial invaders. While Moh. Mahfud MD (2012) argued that to change the constitution, the technical problems of the procedure must be resolved first. These procedural errors relate to who will make substantive changes and the scope of the changes. Thus according to the author of the constitutional amendment can be done, but in the condition of the COVID 19 pandemic, the government should focus more on handling COVID 19, so that the handling carried out by the government and society can be carried out.

\section{Two-Term Presidential Restrictions}

The purpose of limiting the presidential term is to prevent the position of power from continuing to dominate. This is considered the basis for the abuse of power and authority. Therefore, Article 7 of the Constitution was amended in the First Amendment of 1945. It was initially said that "the president and vice president served for five years, and then they could be re-elected." The article said that "the president and vice president served for five years. From then on, he can be re-elected to the same post, but only for one term." It became clearer and more limited, that is, he could only serve two different terms.

According to Sri Soemantri (2015) that the establishment of the power of the President and Vice President at the time of the Amendment of the Constitution of the Republic of Indonesia in 1945 is one of the main agendas. Article 7 of the 1945 Constitution is the first revision process of the 1945 Constitution. This is because the rules contained in Article 7 of the 1945 Constitution are considered too flexible to explain (Latansa, 2019). It can be seen from the six terms from serving as president until Suharto leadership will not be repeated. After the amendment, restrictions on the president's term could prevent authoritarian rule.

The main purpose of the amendment is to verify and maintain balance in every government agency. However, there are still loopholes to be explained in the expression of this article in another sense. For example, the term limits of the president and vice president do not apply continuously or intermittently, and the person in question is already in office. Both terms will no longer be able to occupy the same position during their lifetime.

\section{Three-Term President's Pulse}

As the author explained above, amendments to the 1945 Constitution have undergone many revisions from 1999 to 2002, although it has changed, the insistence and idea of further amendments related to article 7 continue to emerge, especially from JokPro groups and political parties supporting the Indonesian government, which want the presidency to be three terms. These proposals, ideas, and insistences raise pros and cons among academics, political parties, researchers, students, and the public.

According to Jimly Asshiddiqie in AAmaral (2013), The first amendment of the 1945 Constitution was passed in the General Assembly of the MPR-RI which resulted in the ratification of the first amendment text so that it became a historical flaw due to the successful amendment of the 1945 Constitution despite being confronted with conservatives at the time with the desire that the 1945 Constitution not be changed and must be maintained. Amendments to the 1945 Constitution underwent the first amendment, one of which was article 7 which limited the presidential term to two terms. 


\section{Dony Yusra Pebrianto, Sabri Yanto, Yanita Kusuma}

The change in the term of the President and Vice President of Indonesia, from the unlimited to the limited, is the realization of the ideals of the Indonesian people to uphold democracy that adheres to the presidential system of government. But during the COVID19 pandemic, there was a discourse on amendments to article 7 of the 1945 Constitution regarding the tenure of the President and Vice President of Indonesia, from the unlimited to the limited, is an embodiment of the ideals of the Indonesian people to uphold democracy (Nurjamila Siregar, 2019). Therefore the President and vice president-elect, Joko Widodo and Ma'ruf Amin, remain in office until 2024 and their term is not over. Thus, the positions of president and vice president are valid for two terms.

Based on a survey from Research and Consulting (SMRC) some Indonesians rejected the discourse of a three-term term, as well as the results of a survey conducted by the Center for Strategic Actions of Indonesia (CISA) Survey Institute seen from 58.25 percent of respondents who expressed disapproval of the increase in the presidential term to 3 (three) times the survey period, while the Political Chart showed 61.3 percent of the public disagreed with the discourse of the three-term President, As in the picture below.

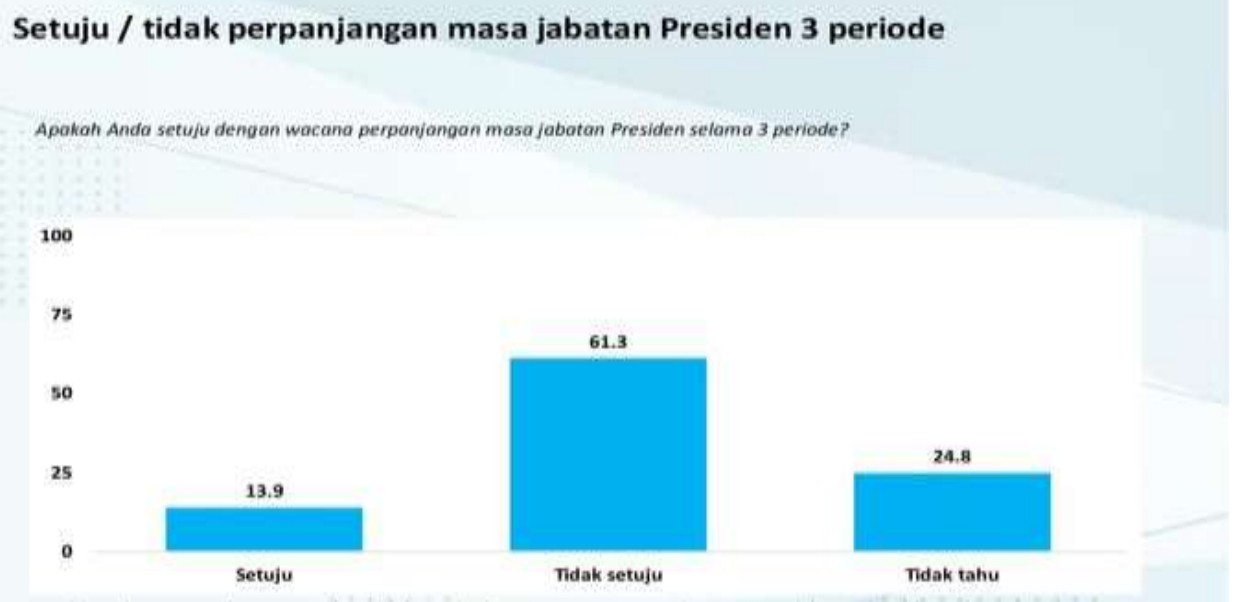

Figure 1

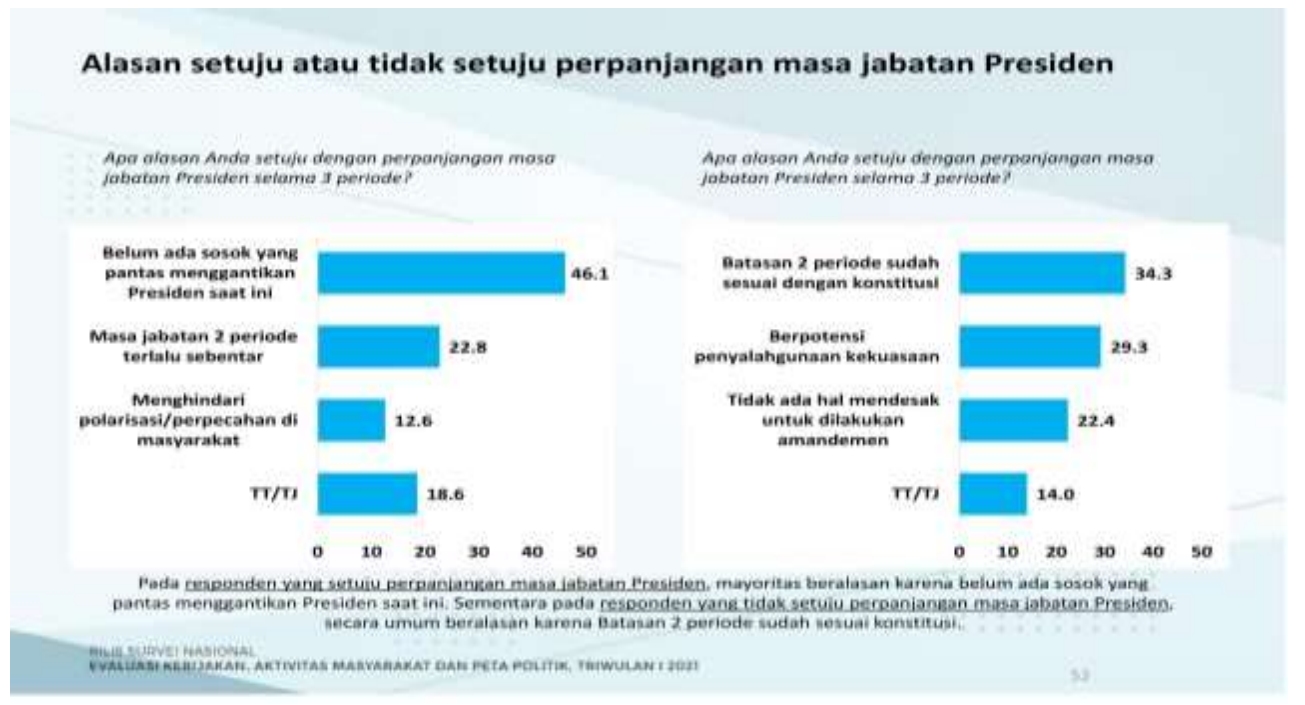

Figure 2 


\section{Setuju atau Tidak: Jokowi Harus Kembali Menjadi Capres di Pemilihan 2024?}

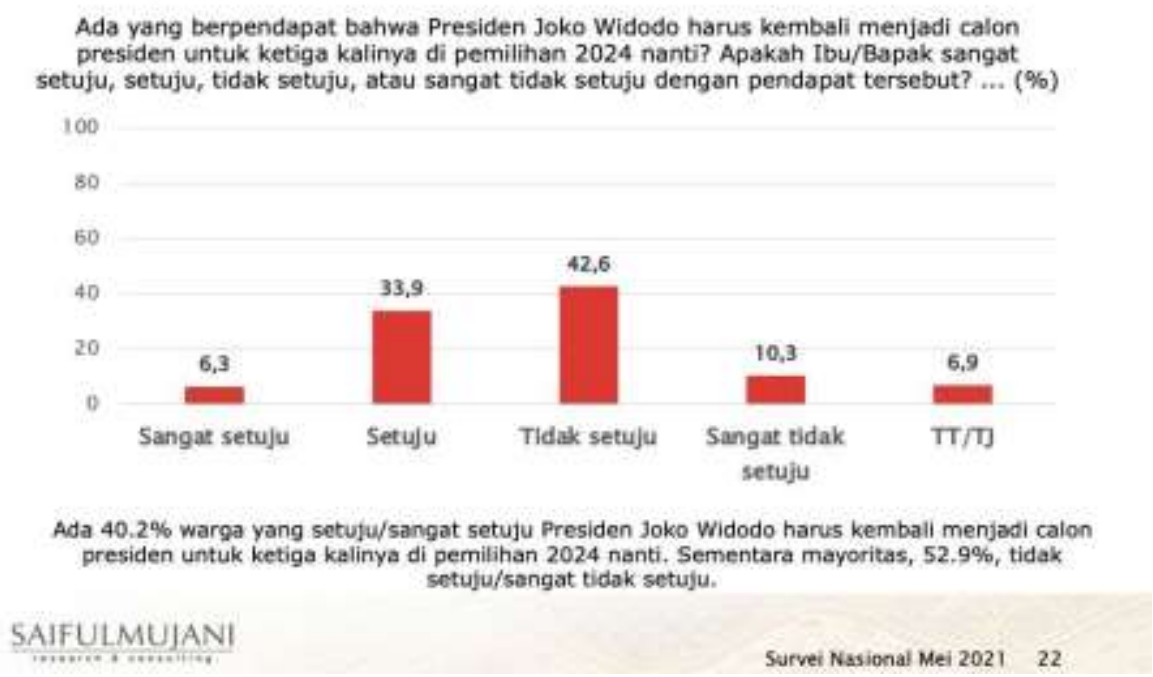

Figure 3

From the picture, it is clear that the discourse of the amendment of the three-term presidential term of the president some Indonesians do not agree or reject, it becomes interesting for the author to be further examined constitutionally with the desire to amend the change of the presidential and vice-presidential terms that were two periods to three periods during the COVID 19 pandemic constitutionally lead to national development in the future.

\section{CONCLUSION}

Based on the above discussion research, the author concluded that the discourse of amendments to article 7 of the 1945 Constitution can be amended under article 37 which reads "To change the articles of the Basic Law, the People's Consultative Assembly Session is attended by at least $2 / 3$ of the number of members of the People's Consultative Assembly".

But on the other hand, the amendments proposed by JokPro groups and political parties supporting the government, should not be rushed or hasty to propose a three-term presidential term. This greatly affects the community when facing the COVID 19 pandemic, as well as the term of the president and vice president, which has not ended his term.

It is better to participate with the government and the community, prevent and deal with the COVID 19 pandemic for public safety and health, so that the realization of a previously abnormal society becomes normal again, as the ideals of the peaceful and prosperous Indonesian people.

\section{REFERENCES}

Amaral, G. (2013). URGENSI KEHADIRAN KOMISI KONSTITUSI DALAM PERUBAHAN UNDANG-UNDANG DASAR 1945. Journal of Petrology, 369(1), 1689-1699. 
Alfianus Danny Jema, Harly Stanly Muaja, M. L. L. (2020). ANALISA HUKUM TERHADAP MEKANISME AMANDEMEN KONSTITUSI (PERUBAHAN UNDANG-UNDANG DASAR) BERDASARKAN SISTEM KETATANEGARAAN YANG BERLAKU DI INDONESIA. VIII(4), 95-103.

Amalia Salabi. (2021). Jabatan Presiden 3 Periode Tidak Konstitusional dan Berbahaya. rumahpemilu.org. https://rumahpemilu.org/jabatan-presiden-3-periode-tidakkonstitusional-dan-berbahaya/

Dicky Eko Prasetio. (2021). Menyoal Gagasan Jabatan Presiden 3 Periode. April, 3-6.

Fransiskus Adhiyuda Prasetia. (2021). Amandemen UUD 1945 ditargetkan terealisasi 2022 supaya Jokowi bisa 3 periode? Kontan.co.id. https://nasional.kontan.co.id/news/amandemen-uud-1945-ditargetkan-terealisasi2022-supaya-jokowi-bisa-3-periode

HRT. Sri Soemantri. (2015). Hukum Tata Negara Indonesia Pemikiran dan Pandangan. PT Remaja Rosdakarya.

Ibrahim, M., \& Fakultas. (2020). Pembatasan Kekuasaan Amendemen Konstitusi : Teori, Praktik di Beberapa Negara dan Relevansinya di Indonesia The Limits of Constitutional Practice in Several Countries and. 17(September).

Jimly Asshiddiqie. (2006). Perkembangan dan Konsolidasi Perkembangan Lembaga Negara Pasca Reformasi (Cetakan ke). Setjen dan Kepaniteraan MKRI.

Kamus Besar Bahasa Indonesia (KBBI). (n.d.). Diambil 5 September 2021, dari https://kbbi.web.id/amandemen KBBI Daring. (n.d.). Diambil 5 September 2021, dari http://kbbi.kamus.pelajar.id/arti-kata/amendemen

Latansa, Q. D. (2019). Konstitusionalitas Batasan Masa Jabatan Presiden dan Wakil Presiden di Indonesia. Jurist-Diction, 2(2), 595. https://doi.org/10.20473/jd.v2i2.14254

M. Yasin Al-Arif. (2017). Aktualisasi Paham Konstitusionalisme dalam Konstitusi Pasca Amandemen Undang Undang Dasar 1945. Pandecta, 12(2), 179.

Moh. Mahfud MD. (2012). Konstitusi dan Hukum Dalam Kontroversi Isu. Raja Grafindo Persada.

Muwaffiq Jupri. (2021). URGENSI AMANDEMEN KELIMA PADA UNDANG-UNDANG DASAR DAN KEBEBASAN BERAGAMA ( The Urgency of The Fifth Amendment of The 1945 Constitution of The Republic Of Indonesia Related To Religious Freedom and Rights ). 123-140.

Nurjamila siregar, H. N. (2019). Uud 1945. 1-54. https://doi.org/10.31227/osf.io/s4vuy

Prasetia, F. A. (2021). Jokpro Optimistis Amandemen UUD 1945 Terealisasi 2022 Agar Presiden Bisa 3 Periode. tribunnews.com.

Prasetyoningsih, N. (2020). Amandemen Ke-5: Menuju Konstitusi Baru Di Indonesia. Hukum Dan Dinamika Masyarakat, 17(2), 162-172. https://doi.org/10.36356/hdm.v17i2.1498

Pusat Studi Hukum Konstitusi Fakultas Hukum UII. (2021). SISI BELAKANG TIGA PERIODE PRESIDEN. https://pshk.uii.ac.id/2021/07/sisi-belakang-tiga-periodepresiden/

Raditya, I. N. (2020). Undang-Undang Dasar 1945 Amandemen UUD 1945 Dilakukan 4 Kali, Sejarah, \& Perubahan Pasal. tirto.id. https://tirto.id/amandemen-uud-1945dilakukan-4-kali-sejarah-perubahan-pasal-f7Cw

Rolando Fransiscus Sihombing. (2021). PKS: Isu Presiden 3 Periode Sudah Berkembang, Ide Amandemen Berbahaya!itle. detikNews.

Survei CISA: Mayoritas Tolak Presiden 3 Periode. (2021). CNN Indonesia.

Syah, T. (2009). AMANDEMEN UUD NEGARA RI TAHUN 1945 MENGHASILKAN SISTEM CHECKS AND BALANCES. 
Syahrizal Sidik. (2021). Survei: Mayoritas Masyarakat RI Tolak Jokowi 3 Periode! CNBC Indonesia.

Syahuri, T. (2010). Metode Perubahan Undang-Undang Dasar 1945 Dan Perbandingannya Dengan Konstitusi Di Beberapa Negara. Jurnal Hukum Ius Quia Iustum, 17(4), 513-529. https://doi.org/10.20885/iustum.vol17.iss4.art1

Wilda Hayatun Nufus. (2021). Survei Charta Politika: 63,1\% Responden Tolak Wacana Presiden 3 Periode. detikNews. 